DOI 10.31558/1815-3070.2020.40.1.3

УДК 811.161.2’367.622

\title{
СИНГУЛЯТИВИ У СУЧАСНІЙ УКРАЇНСЬКІЙ МОВІ
}

У статті розглянуто засоби вираження сингулятивності у сучасній украӥнській мові. Окрім словотвірних сингулятивів, виділяються $і$ засоби на інших мовних рівнях: лексичному, лексико-синтаксичному та граматичному. Найбільше уваги приділено иеентральним засобам - словотоворчим і лесксико-синтаксичним. Запропоновано семантичну класифікацію словотвірних сингулятивів на власне сингулятиви, сингулятиви-фрагментизатори, парні сингулятиви і сингулятиви-підсилювачі.

Ключові слова: одиничність, елемент, виокремлення, опредметнення, сукупність, речовина, словотвірний рівень, лексичний рівень, лексико-синтаксичний рівень, граматичний рівень

Поняття кількості належить до фундаментальних філософських і загальнонаукових категорій. Центр лінгвістичної категорії кількості становить числівник як частина мови, яка називає кількість предметів або осіб. Граматичним центром цієї категорії виступає категорія числа. Відповідно, серед іменників центральну позицію займають ті, що мають повну числову парадигму, тоді як на периферії розташовані іменники з неповною парадигмою числа, зокрема збірні і речовинні іменники. Із збірними і речовинними іменниками корелюють сингулятиви (лат. singularis - одиничний, окремий) - іменникові деривати, які означають предмети, виокремлені із сукупності однорідних предметів або з маси речовини. Виділяючи одиничний предмет із певної сукупності, тобто виокремлюючи елемент маси речовини і опредметнюючи їі таким чином, сингулятиви уможливлюють іï квантифікацію. Одиничні іменники - специфічна риса східнослов'янських мов, зокрма української, і майже відсутні в інших слов'янських мовах. Проте сингулятиви та категорія одиничності, репрезентами якої вони є, в українській мові залишаються недостатньо вивченими.

Сингулятивам найчастіше присвячується кілька рядків або абзаців у підручниках, граматиках, енциклопедіях (СУЛММ; Городенська; Городенська, Кравченко; Горпинич; Олексенко тощо). Словотворчу будову збірних і одиничних іменників у слов’ янських мовах у статті «Словотворча будова збірних і одиничних іменників...» розглядав ще пів століття тому I. I. Ковалик (Ковалик). 3 діахронічної точки зору сингулятиви із суфіксом -ина розглядаються у монографії П. І. Білоусенка і В. В. Німчука Нариси з історії украйнського словотворення (суфікс -ина), з діалектологічної - у статті «Словотвірний розряд іменників зі значенням збірності та одиничності у діалекті лемків» С. Панцьо. Одне з останніх досліджень представлене у статті «Лексико-словотвірні типи сингулятивів...» Л. П. Бойко. Робота Бойко містить перелік сингулятивів із словниковими визначеннями майже кожного з них. Авторка аналізує одиничні іменники 
в першу чергу з точки зору мотивувальних слів, проте без докладного аналізу їхніх семантичних типів. Крім сингулятивів із суфіксом -ина та складним суфік-

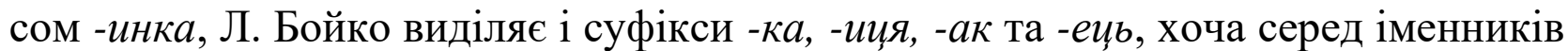
3 цими суфіксами кількість тих 3 власне сингулятивним значенням дуже мала (див. про це нижче). Інші (несловотворчі) засоби вираження сингулятивного значення в українській мові досі не були предметом досліджень, тому мета нашої праці - опис і аналіз різнорівневих засобів вираження одиничності у сучасній українській мові. Отже, предметом нашого дослідження є словотвірні, лексичні і лексико-синтаксичні сингулятиви, а також граматичні засоби вираження сингулятивного значення.

В аналізі фактичного матеріалу застосовано функційний підхід, який полягає у виявленні засобів вираження сингулятивного значення на різних мовних рівнях, з одного боку, та аналіз значення різних типів сингулятивів, спрямований від форми до значення, - з іншого. У рамках такого підходу використані й аналіз словникових визначень та компонентний аналіз.

У роботі вперше визначено репертуар різнорівневих засобів вираження сингулятивності в українській мові, запропоновано семантичну класифікацію словотвірних сингулятивів, які в сучасній українській мові становлять ядро цієї категорії. Результати дослідження можуть бути використані в подальшому опрацюванні загальних питань та часткових проблем, пов'язаних із категорією квантитативності. Практичне значення отриманих результатів полягає в тому, що вони можуть бути використані у навчальному процесі, зокрема у практиці викладання курсу теоретичної граматики і лексикології.

\section{1. Словотвірний рівень}

Матеріалом для нашого дослідження слугували сингулятивні іменники, отримані пошуком за ключовими словами окремий, один, шматок, кусок, частина, часточка і под. в електронному варіанті одинадцятитомного Словника украӥнськой мови і деякі незафіксовані у словнику лексеми (бровина, дощзинка, просинина, редисина, рисина, тесина тощо), взяті із вторинних джерел. Це іменники, переважно утворені за допомогою суфікса -ина та/або складного суфікса -инка, які $\epsilon$ основними виразниками сингулятивного значення на словотвірному рівні. Приблизно половина проаналізованих одиничних іменників має паралельні форми з обома суфіксами, причому похідні з формантом -инка переважно мають додаткове, здрібніло-пестливе забарвлення (див. ще подібні висновки в Олексенко 204-205), пор. виноградина - виноградинка, картоплина - картоплинка, льодина - льодинка. 3 іншого боку, є такі пари, у яких нейтральним є сингулятив iз суфіксом -инка, тоді як похідний на -ина маркований і означає одиничний предмет більшого розміру, пор. сніжинка - сніжина, пушинка - пушина. В інших випадках вибір суфікса зумовлений розмірами предмета, що виокремлюється сингулятивом, пор. цукринка, чаӥнка та худобина, капустина, берестина, а також емоційно-експресивним компонентом, який вносить елемент -к-. Дослідження словотвірних сингулятивів, зокрема з точки зору вживання формантів -ина/-инка, докладніше представлено у статті «Сингулативи као творбена категорија у 
украјинском и њихови еквиваленти у српском језику». У даній же роботі представимо результати аналізу словотвірних сингулятивів лише в загальних рисах.

Сингулятиви найчастіше утворюються від збірних і речовинних іменників. Що стосується збірних імеників, найбільша кількість сингулятивів утворена від іменників collectiva tantum, у яких сингулятив $є$ єдиною формою, якою можна виразити окремий, одиничний предмет, що належить як до гомогенної (бісер бісерина, насіння - насинина, солома - соломина), так і до гетерогенної (одежа (одяг) - одежина, посуд - посудина, сміття - смітина, худоба - худобина) сукупності. Значно рідше сингулятиви утворюються від іменників із значенням регулярної збірності: волос - волосся - волосина, комаха - комашня - комашина тощо. Форма однини останніх або рідше вживається від множини (комаха) - у такому випадку сингулятив ніби дублює значення однини, підкреслюючи виокремленість одиничного предмета: Струменить вітерець, $i$ дихає вільно кожна комашина (Гончар); Але ж зараз біля його вікна ні вітру, ні дерева, ні комашини (Шкляр) $)^{1}$-, або одночасно означає і сукупність предметів, і одиничний предмет, при чому частіше вживається семема із збірним значенням (волос) - у такому випадку сингулятив знімає двозначність форми однини відповідного іменника, пор. Як ото волос на голові, так було пораховано й кожен колосок селянина (Шкляр) і Збудив Марію (...) і попросив у неї волосину (Тарнавський).

До збірних іменників семантично та формально близькі іменники зі значенням речовинності. Підтвердженням цього слугує й утворення сингулятивів від речовинних іменників. Лексико-граматичний розряд іменників на позначення речовини охоплює велику кількість іменників, серед яких є такі, які мають повну числову парадигму (багато назв фруктів, деякі назви овочів тощо). Сингулятиви утворюються як від іменників з неповною парадигмою числа, так і від тих, які частіше вживаються у формах однини та характеризуються обмеженим або специфічним вживанням у формі множини, а саме від іменників на позначення: овочів (горох - горошина, капуста - капустина, картопля - картоплина, квасоля квасолина); рідше фруктів, горіхів (слива - сливина, виноград-виноградина, мигдаль - мигдалина); зернових культур, при чому сингулятив може означати і зернину, і стебло рослини (жито - житина, овес - вівсина, пшениия - пшеничина), або лише зернину (просо - просина, рис - рисина) або лише стебло (сонямник сонямничина, хміль-хмелина); інших, часто диких рослин, які ростуть густо або кущами (бур'ян - бур'янина, лобода - лободина, очерет - очеретина, трава травина), продуктів харчування (иукор - иукринка, чай - чайнка) тощо. До цієї групи можна також віднести іменники типу пил - пилина, порох - порошина і ті, які позначають атмосферні явища: град - градина, дощ - дощинка, лід -льодина, роса - росина, сніг - сніжинка.

Сингулятиви мотивовані й іншими іменниками, для яких характерна відсутність форм однини або частіше вживання у формах множини, зокрема іменниками на позначення парних предметів, наприклад, штани - штанина, кроква -

1 Джерелом усіх прикладів у статті слугував корпус текстів на лінгвістичному порталі http://www.mova.info. 
кроквина, або предметів, що складаються з кількох однакових частин, тобто постають групами: баляси - балясина, буси - бусина, коралі - коралина, намисто намистина, штахети - штахетина (див. також Олексенко 200), віспа - віспина, ряботиння - ряботина тощо.

3 погляду семантики можна виокремити кілька груп словотвірних сингулятивів. Власне сингулятиви позначають один з елементів, з яких складається збірна сукупність або маса речовини. Цей елемент найчастіше найменша видима (у сенсі не наукової, а мовної концептуалізації дійсності ${ }^{2}$ ) частина, яка природно виокремлюється. Така частина більш-менш однакова за формою, розмірами та іншими характеристиками з будь-якою іншою частиною сукупності або маси: волосина, горошина, пилина, піщина, соломина та ін. Сингулятиви, утворені від назв рослин - овочів, фруктів, ягід, позначають найважливіші для людини їстівні частини цих рослин: морквина, перчина, хрінина, цибулина, виноградина, тернина... Для назв зернових культур це їстівні й одночасно найменші елементи зернини: житина, вівсина, просина і под. Або ж це такі елементи, які візуально чітко виокремлюються і вживаються людиною з іншою метою, зокрема стебла: хмелина, лозина і под. Сингулятиви, утворені від назв дерев, незважаючи на їстівність плодів цих дерев, означають одне дерево відповідної рослини: берестина, бучина, вищнина, грабина, кедрина, липина. До власне сингулятивів належать і одиничні іменники типу паркетина, мостина, кроквина, стелина, які позначають однорідні елементи, з яких складається складний предмет.

Сингулятиви-фрагментизатори позначають будь-яку частину збірної сукупності, маси речовини або складного предмета, яка виокремлюється в кожній конкретній ситуації та яка за своїм складом або вмістом однакова іншим частинам цієї сукупності, маси або предмета, але більше чи менше відрізняється від них за своєю формою, розмірами та іншими характеристиками: вуглина, дротина, жерстина, льодина, крижина, прядивина, рогожина, скляничина тощо. У випадках, коли збірний іменник позначає неоднорідну сукупність, предмет, який виокремлюється сингулятивом, близький до інших предметів, що належать до такої сукупності, лише за однією властивістю, найчастіше за функцією: одежина, посудина, смітина, худобина.

Парні сингулятиви позначають одну з двох однакових і симетричних частин, з яких складається предмет, наприклад штани - штанина, дверi - дверина, кроква - кроквина, або один з предметів, які постають парами: брови - бровина, ніздрi - ніздрина (сингулятив функціонує разом із формами однини брова, ніздря). Ця група невелика.

В одиничних іменниках, утворених від іменників, які вже позначають окрему частину якоїсь речовини або сукупності, як-от: крапля - краплина, сльоза - сльозина, іскра - іскрина, стебло - стеблина, стовбур - стовбурина, хмара - хмарина, підкреслюється, підсилюється значення одиничності, тому про них можна говорити, як про сингулятиви-підсилювачі. Суфікс -ина в цих

${ }^{2}$ Наприклад, з наукової точки зору найменша частина води - це молекула. 3 мовною точки зору такою частиною виступає крапля, краплина. 
дериватах має не мутаційну, а модифікаційну функцію, тому ці іменники можна лише умовно віднести до сингулятивів.

Сингулятиви в українській мові утворюються також за допомогою інших

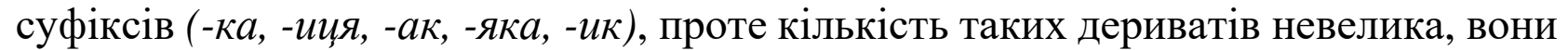
переважно належать до діалектизмів або вживаються в розмовному мовленні, тому їх слід вважати периферійними засобами вираження сингулятивності. Більшість із них (близько 70\%) належить до сингулятивів-фрагментизаторів: ватка, гумка, фанерка; вугляк, гнояк; дерев 'яка («шматок дерева, колода»), залізяка; бобик, вуглик. До власне сингулятивів належать, наприклад, лексема карамельказ, діалектна лексема дерев'яка в одному із своїх значень («окреме дерево»), розмовне товаряка, лексема бобик, а до парних сингулятивів - ворітниця. Сингулятивним можна вважати і значення суфікса -ка у словах курка, гуска, квітка, які утворюють форми множини без цього суфікса - кури, гуси, квіти 4 . Цим перелік сингулятивних дериватів із наведеними суфіксами практично вичерпується. У статті Л. Бойко «Лексико-словотвірні типи сингулятивів...» перелічено ж набагато більше дериватів із цими суфіксами. Річ у тому, що авторка розуміє словотвірні сингулятиви дуже широко. На нашу ж думку, до словотвірних сингулятивів слід відносити лише ті іменники на позначення одиничного предмета, утворені від іменників на позначення цілого (сукупності, маси, складного предмета), з якого виокремлюється відповідний предмет: біб - бобина, бобик, будякбудячина, вата - ватка, ворота - воротниця, ворс - ворсина, град - градинка, жар - жарина, коноплі - коноплина, міст - мостина тощо. Тому, незважаючи на наявність суфіксів, такі деривати, як плитка, планиця, буханка, буханецьь, пластівець та ін., слід віднести не до словотвірних, а до лексико-синтаксичних сингулятивів. У висновках свого дослідження Л. Бойко зазначає, що «в основі семантичного зв'язку твірних слів і похідних сингулятивів лежать логічні відношення цілого та його частини» (Бойко 18), відображені в мові у лексичному відношенні меронімії. І це зауваження абсолютно доречне. Проте між сингулятивністю і меронімією не можна ставити знак рівності. Сингулятиви - лише один iз типів меронімів, для якого характерна подібність частин, які вони позначають, - як однієї до іншої, так і кожної з них до цілого: иукринки, з яких складається цукор, подібні одна до іншої, одночасно кожна цукринка і є цукром (див. про це докладніше у Winston et al. 420-425, Ивановић, «Соматизми као мероними и партикуларизатори» 53-55). Тому такі лексеми, які наводить Л. Бойко, - дужка,

\footnotetext{
${ }^{3}$ Одиничний іменник карамелька корелює із збірним іменником карамель - «сорт твердих цукерок, що їх виготовляють із цукру та патоки (...)». Л. Бойко серед сингулятивів із суфіксом -ка приводить і лексему мармеладка. Проте такої кореляції між іменником мармеладка і речовинним іменником мармелад немає, так само як відповідного відношення «частина - ціле» немає, наприклад, між іменниками иукерка і иукор. Отже, лексему мармеладка не можна вважати словотвірним сингулятивом.

${ }^{4}$ Пор. $з$ іменниками дитина, людина, а також назвами осіб за етнічною або територіальною приналежністю типу слов'янин, киянин, у яких суфікс -ин- $a$, тобто -ин наявний лише у відмінкових формах однини та які дослідники (Ковалик, Горпинич, Дабић, Тихонов, Peti) також вважають сингулятивами.
} 
ніжка, скобка, верхняк, зубець тощо, - належать не до сингулятивів, а до інших типів меронімів.

\section{2. Лексичний рівень}

Іменники з речовинною семантикою нерідко бувають багатозначними. Одна і та ж сама лексема одночасно може позначати і певну матерію й окрему частину цієї матерії, тобто мати і речовинне і сингулятивне значення, пор. камінь «тверда гірська порода у вигляді суцільної маси або окремих шматків, що не кується й не розчиняється у воді» / «окремий шматок, брила такої гірської породи». Назви овочів, фруктів, ягід можуть поєднувати родове, речовинно-збірне i одиничне значення, пор. малина - «багаторічна чагарникова ягідна рослина 3 кисло-солодкими запашними ягодами, звичайно темно-червоного кольору» / «ягоди цієї рослини» / «одна ягода цієї рослини» або морква - «городня рослина 3 пірчасто-розсіченими листками й довгастим потовщеним коренем» / «коренеплоди цієї рослини оранжевого кольору, що вживаються як їжа або корм» / «один коренеплід цієї рослини». У такому випадку можна говорити про вираження сингулятивності на лексичному рівні, при чому одиничне значення можна диференціювати лише в контексті: Каже, грунт гарний, дрібний камінь / Водолази старанно оглядали кожен камінь на дні, зазирали в кожну щъілину між камінням (Трублаїні); Треба витягти з льоху капусту і моркву (Хома) / А коли він схопив 3 гілки лялькову моркву і скривився (...), дівчинка принесла йому справжню моркву, i він весело захрумтів (Іваненко). Конкуренція значень в рамках однієї лексеми, велика роль контексту, рідке вживання у формах множини і взагалі в одиничному значенні, обмежені можливості сполучуваності з числівниками зумовлюють периферійність лексичних засобів у вираженні сингулятивності, а мова розвиває інші механізми, які знімають зазначені обмеження - словотвірні сингулятиви (морква - морквина), аналітичні сингулятиви (малина - ягода малини), граматичне розмежовування (Р.в. каменя - каменю). Особливості функціонування форм числа іменників на позначення овочів, фруктів, ягід у деяких слов'янських мовах були предметом кількох досліджень (Ivić, Wierzbicka, Мустайоки), але в жодному з цих досліджень ні, наскільки нам відомо, в інших роботах ці особливості не аналізувались на матеріалі української мови. Результати такого аналізу, разом із аналізом вживання закінчень $-a(-я) /-y(-ю)$ у назвах рослин, на нашу думку, були б дуже корисними для вивчення сингулятивності також.

Дуже рідко сингулятивність виражається окремою лексемою, яка, інкапсулюючи значення відповідного цілого, словотвірно не пов'язана з ним: холоша штани (разом із штанина); планка - огорожа; бухан, буханка, буханець - хліб; бульба - картопля та ін. Ступінь інкапсуляції значення цілого в цих лексемах, на відміну від лексико-синтаксичних (аналітичних) сингулятивів, максимальний, тому вони здатні виражати одиничну семантику не лише у сполученні із відповідними іменниками, як аналітичні сингулятиви, але й самостійно: Закачавщи повище холоші, вони бродили по річечщі (Дімаров) / Сашко закотив ліву холошу штанів (Загребельний); Для n'ятьох буханка на день - в обріз (Самбук) / Жінка поставила перед ним буханку хліба, масло й кухоль молока (Бойчук). 


\section{3. Лексико-синтаксичний рівень}

Сингулятивна семантика в українській мові може виражатися і на лексикосинтаксичному рівні за допомогою спеціальних лексем-квантифікаторів. Лексеми $з$ цією функцією порівняно широко досліджувалися в інших мовах, зокрема у зв'язку із т. зв. класифікаторами (Lehrer, Allan, Aikhenvald тощо). Оскільки для східнослов'янських мов характерні словотвірні сингулятиви, цей спосіб вираження одиничності майже не привертав увагу дослідників. У монографії «Сучасна українська літературна мова: морфологія» I. I. Ковалик лише коротко зауважує, що «одиничні назви утворюються також аналітичним способом за допомогою особливих іменників: одна головка часнику, три ягоди малини» (СУЛММ 67). У статті «Специфика сингулятивов» болгарська славістка I. Атанасова досліджує сингулятивність у російській мові, розрізняючи прості (однослівні) і описові (складні) сингулятиви. Із класифікації останніх на семантичні групи видно, що ця авторка дуже широко розуміє аналітичні сингулятиви, серед яких, крім лексем типу качан, головка, стручок і под., зустрічаються і одниці міри (кілограм, літр...), назви посудин, вмістилищ (тарелка, миска, стакан та ін.), назви різних видів упаковок (пачка, мешок, тюбик тощо) і навіть лексема грузовик (Атанасова 15). Говорячи про відношення між простими і описовими сингулятивами, I. Атанасова зазначає, що сингулятиви «виникли для вимірювання кількості речовини: для такої, що складається з окремих однорідних екземплярів, крупинок, часточок (предметів), які можна побачити неозброєним оком, - прості, а для неподільної речовини - описові» (Атанасова 10). Така позиція авторки дискусійна, позаяк, на нашу думку, функція «вимірювання кількості» для сингулятивів не $є$ основною. Основна функція одиничних іменників - опредметнити масу речовини або певну сукупність, називаючи звичайну частину або елемент такого цілого, тоді як функція квантифікації $є$ вторинною, і реалізується саме завдяки цьому опредметненню. Тому лексеми типу кілограм, тарілка, мішок не слід відносити до аналітичних сингулятивів. 3 іншого боку, аналітичні сингулятиви можуть називати елементи і тих речовин або сукупностей, що складаються з «однорідних екземплярів, крупинок, часточок (предметів), які можна побачити неозброєним оком» - наприклад ягода, капля, головка, які І. Атанасова згадує, але не включає до своєї класифікації.

Отже, на лексико-семантичному рівні сингулятивність виражається за допомогою т. зв. аналітичних сингулятивів - лексем, які називають певну частину маси речовини або елемент сукупності, при чому така частина або елемент більш або менш однакові за складом (вмістом), формою, розмірами тощо з іншими частинами. Тоді як словотвірні (тобто синтетичні) сингулятиви зазвичай називають найменшу одиницю, яку можна виокремити (виноградина, кровинка), аналітичні можуть називати і найменший елемент (ягода винограду, крапля крові, зерно кукурудзи), але й більшу, природно виокремлювану частину (гроно винограду, цівка крові, качан кукурудзи). Аналітичні сингулятиви, на відміну від власне лексичних, одиничне значення виражають лише в рамках конструкцій із відповідним іменником у формі родового відмінка однини (див. приклади 
нижче) або, рідше, з прикметником: манна крупинка, ячмінна зернина, кавове зернятко, капустяний качан, дощзова краплина тощо.

У функції аналітичних сингулятивів в українській мові виступають такі лексеми (в алфавітному порядку): аркуш (паперу, картону, фанери), брила (каменю, каміння, землі, глини, льоду, снігу, металу), брусок (мила, цегли, масла, сиру, сала), волокно (шовку, бавовни, водоростей), волос, волосина, волоска (ворсу, шерсті), гілка, гілочка (петрушки, кропу), головка (цибулі, часнику, капусти, цьвітної капусти, брюсельської капусти, салату, будяка), горіх, горішок (мигдалю, арахісу), зерно, зернятко, зернина (кукурудзи, ячменю, пшениці, проса, рису, маку, кінзи, сочевиці, конопель, арахісу, піску, кромхмалю, кави, ікри, землі), качан (капусти, кукурудзи), крапля, краплинка (води, крови, молока, дощу, роси), кристал, кристалик (снігу, льоду, иукру, солі, граду, квариу, алмазу, топазу), крупина, крупинка (граду, снігу, иукру, солі, борошна, каші, спецій, піску, землі, золота, пороху, сажі), кулька (дробу, шроту), лист, листок (ипинату, салату, капусти, базиліку, жерсті), корінь, корінець, корінчик (петрушки, хріну, ріпи, селери, моркви, імбиру), насінина (гороху, бобу, проса, гречки), пелюстка (чаю), стебло, стеблина (петрушки, кропу, спаржі, очерету, комишу, пшениці, кукурудзи, трави, конопель, сіна, соломи), стручок (спаржі, квасолі, перцю), ичибулина (порею, часнику), цівка, цівочка (повітря, диму, запаху, смороду, води, крові, молока, поту, мікстури), часточка, частинка (пилу, пороху, пуху, дерева, кврацу, кришталю), ягода, ягідка (чорниџь, брусницьь, смородини, малини, журавлини, кизилу, бузини, пасльону, агрусу, иовковиці, ізюму, вишні, черешні) тощо. Звернемо увагу і на лексему предмет, яка функціонує як сингулятив на позначення елемента неоднорідної сукупності: предмет - одягу, взуття, білизни, меблів, багажу, обладнання, техніки та ін. Для виокремлення елемента сукупності істот типу флора, фауна, населення, молодь вживається сингулятив представник. На окрему увагу, заслуговують і лексеми типу шматок, кусок, які характеризуються надзвичайно широкою сполучуваністю і позначають будь-яку частину якоїсь матерії, тобто є сингулятивами-фрагментизаторами, пор. вуглина- шматок вугілля, крижина - шматок криги, скляничина - шматок скла; шматок (кусок) м'яса, сала тощо.

Наш перелік аналітичних сингулятивів, отриманий пошуком у електронному словнику за такими самими ключовими словами, як для словотвірних сингулятивів, а також, додатково, за допомогою пошуку у корпусі (http://www.mova.info/corpus.aspx) за речовинними іменниками у формі родового відмінка однини, не є вичерпним і остаточним. Однак цей перелік достатній для ілюстрації аналізованих явищ та як вступ або імпульс до подальших досліджень, які охоплювали би такі питання: 1. Відношення між аналітичними сингулятивами та іншими засобами вираження сингулятивності: у деяких випадках одиничне значення можна виразити лише на лексико-синтаксичному рівні (краплина води, брусок мила, гілочка кропу, зернина кукурудзи і под.), в інших паралельно - на лексико-синтаксичному та якомусь іншому рівні (дощина - краплина дощу, зерно піску - пішина, кристалик снігу - сніжинка, крупинка иукру - цукринка тощо), або інших рівнях (цегла - цеелина - брусок цчегли, цчибуля - цчибулина - 
головка циибулі і под.); 2. Включення змісту іменника, який називає речовину або сукупність, до значення сингулятива та характеристики сполучуваності аналітичних сингулятивів, наприклад: сингулятиви крапля, краплина сполучаються лише з іменниками на позначення рідини або рідкої речовини (вода, молоко, сік, вино, кава, мед, віск, фарба, кров, nim, дощ, роса та ін.), тоді як сингулятиви ців$\kappa a$, цівочка сполучаються з іменниками на позначення рідини або рідкої матерії (вода, кров, молоко, nim, мікстура тощо), а також з іменниками, які означають газувату речовину (повітря, дим) або навіть явища, які поширюються у повітрі (запах, сморід); лексеми зерно, зернина, зернятко сполучаються з іменниками, які називають масу/сукупність, частини яких $\epsilon$ маленькими, круглими та твердими; крім того, деяким лексемам властива широка сполучуваність (напр. ягода, ягідка; зерно, зернятко, зернина; крупина, крупинка), іншим - дуже вузька (цибулина, качан); 3 . Переносне вживання деяких сингулятивів у функції експресивної квантифікації малої кількості в колокаціях з абстрактними іменниками: крупинка - рачії, досвіду, совісті, життя, безсмертя; зернина, зернятко - правди, добра, байдужості, підозри, пам'яті, розуму; крапля - страху, шовінізму, співчуття, снаги, сили тощо.

\section{4. Граматичний (морфологічний) рівень}

В українській мові іменники чоловічого роду у родовому відмінку однини залежно від свого значення можуть мати закінчення - $a(-я)$ або - $y(-ю)$. Спектр значень, які зумовлюють вживання того чи іншого закінчення, досить широкий, проте в основі розмежовування лежать семи предметності і конкретності: іменники, які мають ці семи, тобто позначають конкретні предмети (звичайно ж, у широкому розумінні) мають закінчення - $a(-я)$. Оскільки, як ми вже зазначили, функцією сингулятива є виокремлення одиничного предмета (елемента) із маси речовини або сукупності, в багатозначних іменників, які в одній формі поєднують речовинну або збірну семантику, з одного боку, і сингулятивне (конкретнопредметне) значення, -з іншого, вживання того чи іншого закінчення сигналізує про реалізацію відповідної семеми. Пор.: Магазаник (...) поглянув на молоду голівку соняшника, щзо стояла в глечику на столі (Стельмах) й $А$ за ними - коричневу смужку дороги між жовто-зеленим лісом соняшнику (Роздобудько); Я дав буряка йому з руки (Вінграновський) і Куля брала участь у районній нараді по забезпеченню вивезення буряку (Щербак); Дякувати Богові, і трупа ніде не було (Шкляр) та I куди не пойхати, куди не піти - всюди несло духом непохованого людського трупу (Довженко).

Словник у рамках граматичного довідника Н. Є. Лозової «Іменник» фіксує 62 такі іменники. Серед них виділяються дві велики групи. До першої належать назви мінералів або коштовного каміння: авантюрин, агат, аквамарин, алмаз, аметист, ізумруд, олександрит, онікс, опал, смарагд, топаз тощо, у яких закінчення - $a$ вживається при реалізації семеми «окремий кристал», а флексія - $y$ - семеми «речовина». Пор.: То був товстий золотий перстень із тьмяним камінцем смарагда (Білик) та I щзо підвалини його зроблені з каменю: яспису, сапфipy, халкидону, смарагду (Дереш). 
До другої групи відносяться назви дерев: бук, в'яз, горіх, граб, дуб, каштан, клен, тик, тис, явір, ясен тощо, а закінчення -а(-я) вживається у значенні «одне дерево», -у(-ю) у значенні «деревина». Пор.: Ти даєш мені нюхати кору священного тиса (Дереш) і На стояки й палубні сволоки ми візьмемо червонавого, густого тису (Яновський). У наступних прикладах реалізується збірне значення: Ховаючись у чагарниках молодого клену (...) я добрався до иентральної вулиці (Чех); Поміж фруктових дерев - стрункі ряди кипарисів, кущі жасмину, мімози, герані, тису та розмарину (Мушкетик).

Решта іменників досить різноманітні, але й тут закінчення - $a(-я)$ пов'язане із позначенням одиничного предмета, а $-y(-ю)$ - із збірним або речовинним значенням: брикет, - $a$ (одиничний предмет) і -y (збірне); буряк, - $a$ (один корінь) i -y (збірне); волос, - $-a$ (те саме, що волосина) і -y (те саме, що волосся); інструмент, - $a$ (окремий предмет) і -y (сукупність предметів); камінь, -меню (маса, матеріал; хвороба) і -меня (окремий уламок; пам'ятник; жорно); краснопір, -пера (одна рибина) і -перу (збірне); сирок, -a (один) і -y (маса); соняшник, -a (одна рослина, квітка) і -y (збірне), mpyn, - (мертве тіло) і -y (збірне) тощо. Пор.: Фрази нагадували Маркусові кола на воді від впущеного каменя (Прохасько) і Це була велика вілла, збудована з білого каменю (Бойчук); При нестачі сірки жилки листа, як $i$ всі інші ділянки листа, стають світло-зеленими та Але ще десь світиться плід між ріденьким золотом листу (Матіос).

Слід зазначити і те, що у корпусі зустрічається немало прикладів ${ }^{5}$ вживання закінчення - $a(-я)$ при реалізації семеми із збірною семантикою, наприклад: $A \underline{c o-}$ няшника, а маку, буряків, лободи, укропу, моркви! (Довженко); Розкинулися плантації иукрового буряка (Смолич) тощо.

Отже, виокремлення індивідуалізованих, дискретних предметів із збірної сукупності або маси речовини здійснюється в українській мові за допомогою засобів різних мовних рівнів: 1) словотвірного: горох - горошина; 2) лексичного: великий камінь - транспорт каменю - будинок з каменю; 3) лексико-синтаксичного: качан капусти; та 4) граматичного: взяти інструмента - набір інструменту. 3 одного боку, вживання одиничних іменників як синтетичних засобів економічніше, ніж використання аналітичних конструкцій, пор. капустина - качан капусти. 3 іншого боку, можливості вираження сингулятивного значення на лескико-семантичному рівні, на відміну від словотвірного, практично не обмежені. Словотвірні сингулятиви, як правило, однозначні ${ }^{6}$, що спричиняє їхню перевагу над лескичними засобами, пор. морквина - морква. Вираження одиничності на граматичному рівні обмежене іменниками чоловічого роду. Зважаючи на це, у сучасній українській мові центральними $є$ словотворчі і лексико-синтаксичні засоби.

${ }^{5}$ Наприклад, у корпусі художньої прози форма соняшника вживається при реалізації семеми із збірною семантикою у 38 \% усіх прикладів, у корпусі публіцистики - у 95 \%. Одночасно, усі приклади вживання форми соняшнику в художньому і публіцистичному корпусах пов'язані саме із збірним значенням.

6 Звичайно ж, і тут є винятки, наприклад, іменник одежина позначає «що-небудь з одягу; окрему складову частину одягу», але може означати і те саме, що збірне одяг; лексема худобина може мати і одиничне, і збірне значення. 
Можна виокремити кілька семантичних груп словотвірних сингулятивів: власне сингулятиви (горошина), сингулятиви-фрагментизатори (вуглина), парні сингулятиви (штанина) і сингулятиви-підсилювачі (краплина). Серед аналітичних сингулятивів також можна розрізняти власне сингулятиви (зернина кукурудзи) і сингулятиви-фрагментизатори (шматок м'яса). Із словотвірними парними сингулятивами співвідносні конструкції один з, будь-хто з, той з та ін. + іменник у родовому відмінку: один з подружжя; будь-хто з батьків; той з молодят, хто...

Відношення «одиничне - сукупне» характерне не лише для іменників, але й для дієслів. Мультиплікативи, тобто багатократні дієслова, можна назвати і збірними дієсловами, оскільки вони, позначають обмежену невизначену сукупність однорідних дій (так само як збірні іменники - предметів), інтерпретованих мовцем як одне ціле: блимати, каркати, кліпати, махати, рипати, стукати тощо, тоді як утворені від них за допомогою суфікса -ну-семельфактиви, тобто однократні дієслова, можна вважати сингулятивними дієсловами, оскільки вони виокремлюють одну з однорідних дій (так само як одиничні іменники виокремлюють один з елементів), що складають мультиплікативну сукупність - блимнути, каркнути, кліпнути, махнути, рипнути, стукнути і под. (Ивановић, «Акционалност : семантика и форма у савременом украјинском и српском језику» 190191, 200).

\section{Література}

1. Атанасова И. Специфика сингулятивов. Folia Linguistica Rossica. 2012. № 8. С. 9-17.

2. Білоусенко П. І., Німчук В. В. Нариси з історії українського словотворення (суфікс -ина) : монографія. Запоріжжя - Ялта - Київ : ТОВ «ЛІПС», 2009. 252 с.

3. Бойко Л. П. Лексико-словотвірні типи сингулятивів (на матеріалі одинадцятитомного «Словника української мови»). Науковий вісник Міжнародного гуманітарного університету. Серія: Філологія. 2018. № 33. т. 1. С. 16-19.

4. Городенська К.Г. Одиничні іменники. Украйнська мова : енциклопедія / редкол.: В. М. Русанівський, О. О. Тараненко, М. П. Зяблюк та ін. Київ : Українська енциклопедія, 2000. C. 394.

5. Городенська Г.К., Кравченко М.В. Словотвірна структура слова : монографія. Київ : Наукова думка, 1981. 199 с.

6. Горпинич В. О. Морфологія української мови : підручник для студентів вищих навчальних закладів. Київ: Видавничий центр «Академія», 2004. 336 с.

7. Дабић Б. Белешке о категорији јединичности у српском језику. Наш језик. 2000. № 33. т. 3-4. C. 198-203.

8. Ивановић М. Акционалност: семантика и форма у савременом украјинском и српском језику. Београд : Филолошки факултет Универзитета у Београду, 2016. 357 с.

9. Ивановић М. Сингулативи као творбена категорија у украјинском и њихови еквиваленти у српском језику. Универзитетска славистика: традииије, савремено стање, перспективе : Међународни научни зборник поводом 140 година Катедре за славистику Београдског универзитета / уред. К. Кончаревић. Београд : Филолошки факултет, 2017. С. 393-405.

10. Ивановић М. Соматизми као мероними и партикуларизатори. На материјалу српског и украјинског језика. Трагом славистичких истражсивања професора Богољуба Станковића : међународни научни зборник радова / уред. К. Кончаревић. Београд : Савез славистичких друштава Србије: Филолшошки факултет, 2018. С. 51-67. 
11. Ковалик I. І. Словотворча будова збірних і одиничних іменників у східнослов'янських мовах у порівнянні з іншими слов'янськими мовами. Питання слов'янського мовознавства. Львів : Вид-во Львів. держ. ун-ту, 1958. кн. 6. С. 18-55.

12. Лозова Н. С. Іменник. Граматичний довідник. Київ : Наукова думка, 2016. 288 с.

13. Мустайоки А. Грамматическое число у названий фруктов, овощей и ягод в русском и финском языках. Языковая личность: текст, словарь, образ мира : к 70-летию члена-корреспондента РАН Ю.Н. Караулова : [сб. ст.]. Москва : Изд-во РУДН, 2006. С. 447-463.

14. Олексенко В.П. Словотвірні категорії іменника: монографія. Херсон: Айлант, 2005. 336 с.

15. Панцьо С. Словотвірний розряд іменників зі значенням збірності та одиничності у діалекті лемків. Наукові записки. Серія: Філологічні науки (мовознавство). Кіровоград : РВЦ КДПУ ім. Володимира Винниченка, 2000. Вип. 23. С. 23-30.

16. Словник української мови. URL: http://sum.in.ua/ (дата звернення: 11.07.2020).

17. Сучасна українська літературна мова. Морфологія / Бараник, Дмитро, Іван Ковалик, А. С. Колодяжний, Л. І. Коломієць, А. В. Майборода, І. Г. Матвіяс, М. П. Муравицька; відп. ред. В. М. Русанівський ; за заг. ред. І. К. Білодіда. Київ : Наукова думка, 1969. 583 с.

18. Тихонов А. Н. Современный русский язык. Морфемика. Словообразование. Морфология : учеб. пособие. Москва : Цитадель-трейд, 2002. 423 с.

19. Aikhenvald A. Classifiers. A typology of Noun Categorization Devices. Oxford : Oxford University Press, 2000. xxvi+535 p.

20. Allan K. Classifiers. Language. 1977. № 53/2. P. 285-311.

21. Ivić M. Slavic Fruit and Vegetable Names and Countability. International Journal of Slavic Linguistics and Poetics. 1982. № XXV/XXVI. P. 209-211.

22. Lehrer A. English Classifier Constructions. Lingua .1986. № 68. P. 109-148.

23. Peti M. Zbrojina. Rasprave Instituta za hrvatski jezik i jezikoslovlje. 2001. knj. 27. S. 209-250.

24. Wierzbicka A. The semantics of grammar. Amsterdam; Philadelphia : John Benjamins, 1988. x $+617 \mathrm{p}$.

25. Winston M., Chaffin R., Herrmann D. A Taxonomy of the Part-Whole Relations. Cognitive Science. 1987. № 11. P. 417-444.

\section{References}

1. Aikhenvald, Alexandra. Classifiers. A typology of Noun Categorization Devices. Oxford : Oxford University Press, 2000. Print.

2. Allan, Keith. "Classifiers". Language 53/2 (1977): 285-311. Print.

3. Atanasova, Ivanka. "Spetsyfyka synhulyatyvov (Specificity of singulatives)". Folia Linguistica Rossica 8 (2012): 9-17. Print.

4. Bilousenko, Petro. and Vasyl' Nimchuk. Narysy z istoriyi ukrayins'koho slovotvorennya (sufiks yna) (Outline from the history of the Ukrainian word creation (sufiks -ina)). Zaporizhzhya - Yalta - Kyyiv : TOV "LIPS", 2009. Print.

5. Boyko, Larysa. "Leksyko-slovotvirni typy synhulyatyviv (na materiali odynadtsyatytomnoho 'Slovnyka ukrayins'koyi movy') (Lexical and word-building types of singulatives (on materials of eleven volum 'Dictionary of the Ukrainian language'))". Naukovyy visnyk Mizhnarodnoho humanitarnoho universytetu. Seriya: Filolohiya. 33 (2018). Vol. 1: 16-19. Print.

6. Horodens'ka, Kateryna. „Odynychni imennyky (Singulatives)“. Ukrayins'ka mova : entsyklopediya / Ed. by. Vitaliy Rusanivs'kyy et al. Kyyiv: Ukrayins'ka entsyklopediya, 2000. Print

7. Horodens'ka, Kateryna and Mariya Kravchenko. Slovotvirna struktura slova (Word structue and word formation). Kyyiv: Naukova dumka, 1981. Print.

8. Horpynych, Volodymyr. Morfolohiya ukrayins'koyi movy : pidruchnyk dlya studentiv vyshchykh navchal'nykh zakladiv. Kyyiv: Vydavnychyy tsentr „Akademiya“, 2004. Print

9. Dabić, Bogdan. "Beleške o kategoriji jediničnosti u srpskom jeziku (Notes on the category of singulativity unity in the Serbian language)". Naš jezik. 33 (2000). Vol. 3-4: 198-203. Print. 
10. Ivanović, Milena. Akcionalnost: semantika i forma u savremenom ukrajinskom i srpskom jeziku (Aktionsart: semantics and form in Ukrainian and Serbian Languages). Beograd : Filološki fakultet Univerziteta u Beogradu, 2016. Print.

11. Ivanović, Milena. "Singulativi kao tvorbena kategorija u ukrajinskom I njihovi ekvivalenti u srpskom jeziku (Singulatives as word-formation category in the Ukrainian Language and their equivalents in Serbian Language)". Univerzitetska slavistika: tradicije, savremeno stanje, perspektive: Medjunarodni naučni zbornik povodom 140 godina Katedre za slavistiku Beogradskog univerziteta / Ed. by. Ksenija Končarević. Beograd: Filološki fakultet, 2017: 393405. Print.

12. Ivanović, Milena. "Somatizmi kao meronimi i partikularizatori. Na materijalu srpskog i ukrajinskog jezika (Somatisms as meronyms and particularizers in the Serbian and Ukrainian Language)". Tragom slavističkih istraživanja profesora Bogoljuba Stankovića: medjunarodni naučni zbornik radova / Ed. by. Ksenija Končarević. Beograd: Savez slavističkih društava Srbije: Filološki fakultet, 2018: 51-67. Print.

13. Ivić, Milka. "Slavic Fruit and Vegetable Names and Countability". International Journal of Slavic Linguistics and Poetics. XXV/XXVI (1982): 209-211. Print.

14. Kovalyk, Ivan. "Slovotvorcha budova zbirnykh i odynychnykh imennykiv u skhidnoslov"yans'kykh movakh u porivnyanni z inshymy slov"yans'kymy movamy (Word-formation structure of collective and singulative nouns in East Slavic languages in comparison with other Slavic languages)". Pytannya slov"yans'koho movoznavstva. L'viv : Vyd-vo L'viv. derzh. un-tu. Vol. 6 (1958): 18-55. Print.

15. Lehrer, Adrienne. "English Classifier Constructions". Lingua. 68 (1986): 109-148. Print.

16. Lozova, Nina. Imennyk. Hramatychnyy dovidnyk (Noun. Grammar guide). Kyyiv: Naukova dumka, 2016. Print.

17. Mustayoki, Arto. "Grammaticheskoe chislo u nazvanij fruktov, ovoshchej i jagod v russkom i finskom jazykah (Grammatical number of Fruit, Vegetable and Berries Names in Russian and Finnish languages)". Jazykovaja lichnost': tekst, slovar', obraz mira: k 70-letiju chlenakorrespondenta RAN Ju.N. Karaulova: [sb. st.]. Moskva : Izd-vo RUDN, 2006: 447-463. Print.

18. Oleksenko, Volodymyr. Slovotvirni katehoriyi imennyka (Word-formation categories of the noun). Kherson: Aylant, 2005. Print.

19. Pants'o, Stefaniya. "Slovotvirnyy rozryad imennykiv zi znachennyam zbirnosti ta odynychnosti u dialekti lemkiv (Word-formation categories of collective and singulative nouns in the Lemko dialect)". Naukovi zapysky. Seriya: Filolohichni nauky (movoznavstvo). Kirovohrad: RVTs KDPU im. Volodymyra Vynnychenka, Vyp. 23 (2000): 23-30. Print.

20. Peti, Mirko. "Zbrojina (Zbrojina - collective number)". Rasprave Instituta za hrvatski jezik $i$ jezikoslovlje. 27 (2001): 209-250. Print.

21. Slovnyk ukrayins'koyi movy (Dictionary of the Ukrainian language). URL: http://sum.in.ua/. Web. 11 July 2020.

22. Suchasna ukrayins'ka literaturna mova. Morfolohiya (Contemporary Ukrainian literary Language. Morphology) / Baranyk, Dmytro, Ivan Kovalyk et al. / Ed. by. Vitaliy Rusanivs'kyy and Ivan Bilodid. Kyyiv : Naukova dumka, 1969. Print.

23. Tihonov, Aleksandr. Sovremennyy russkiy yazyk. Morfemika. Slovoobrazovanie. Morfologiya (Contemporary Russian Language. Morphemics. Word formation. Morphology). Moskva: Citadel'-treyd, 2002. Print.

24. Wierzbicka, Anna. The semantics of grammar. Amsterdam; Philadelphia: John Benjamins, 1988. Print.

25. Winston, Morton, Roger Chaffin and Douglas Herrmann. "A Taxonomy of the Part-Whole Relations". Cognitive Science. 11 (1987): 417-444. 


\section{ON SINGULATIVES IN CONTEMPORARY UKRAINIAN LANGUAGE}

Milena Ivanović

Department of Slavonic Studies, Faculty of Philology, University of Belgrade

Abstract

Background: Singulatives denote objects separated from a collection of uniform (homogenous) objects or from a structural mass. This separation materializes the collection, i.e., mass, which enables their quantification. Derivational singulatives such as горошина represent a specific trait of East Slavic, and among those also the Ukrainian language. The meaning of singulativity is, however, expressed not only at the derivational level but also at other levels of language, which has not yet been the subject of special study.

Purpose: The aim of our research is the description and analysis of the means for expressing singulative meaning at different levels of language.

Results: In the Ukrainian language, singulativity is expressed at the: 1. Derivational level, where the main means of expression is the suffix $-u н а$, that is the compound suffix - инка (горохгорошина, иукор-иукринка); 2. Lexical level, through one of the meanings of a polysemic lexeme, whereby it is only manifested in context (камінь - великий камінь/транспорт каменю/будинок $з$ каменю), 3. Lexical-syntactic level, through special lexeme-quantifiers such as головка, зерно, ягода, in constructions with an adjective or a noun (каквове зернятко, зернятко кави), and 4. Grammatical level, where it is limited to the genitive singular form of polysemic masculine nouns, in which the suffix $-a(-\Omega)$ is used in the realization of a singulative sememe, and $-y(-\wp)$ in the realization of collective meaning (взяти інструмента - набір інструменту).

Discussion: The central means for expressing singulativity are those at the derivational and lexical-syntactic level. In that, singulatives most often denote the smallest visible element of a collection or mass which is naturally separated and which is equal in its composition, shape, size, etc. with any other element of that collection or mass (singulatives in the narrow sense: иибулина, головка цибулі); they can also denote any part of a collection, mass or complex object that is separated in every specific situation and which is equal in composition with the other parts, from which it can differ in shape, size etc. (singulatives-fragmentators: вуглина, шматок вугілля); finally, they can denote one of two equal and symmetrical parts of an object or one of two objects that usually go together (pair singulatives: штани - итанина, батьки - один у батьків) or they can only have a modifying, amplifying function (singulatives-amplifiers: краплина). The collective/individual relationship is also characteristic of verbs: кліпати/кліпнути.

Keywords: singulativity, element, separation, materialization, collection, structural mass (matter), derivational level, lexical level, lexical-syntactic level, grammatical level

Vitae

Milena Ivanović is a Doctor of Philology, Associate Professor at the Department of Slavonic Studies, Faculty of Philology, University of Belgrade. Areas of research interests include functional linguistics, comparative linguistics, translation studies.

Correspondence: ivanovic.milena@gmail.com

Надійшла до редакції 4 вересня 2020 року Рекомендована до друку 24 вересня 2020 року 